\title{
Anti-cancer effect of farrerol induced apoptosis through activating p38 MAPK in Human breast cancer MCF-7 cells
}

\author{
Jongbeom Chae ${ }^{1} \cdot$ Seul Gi Lee ${ }^{1} \cdot$ Ju-Ock Nam ${ }^{1,2}$ (D)
}

\section{인간 유방암 세포주 MCF-7에 대한 farrerol의 p38 MAPK 활성화와 세포사멸 유도를 통한 항암 효과}

채종범 ${ }^{1} \cdot$ 이슬기 ${ }^{1} \cdot$ 남주옥 ${ }^{1,2}$

Received: 27 February 2020 / Accepted: 18 May 2020 / Published Online: 30 June 2020

(C) The Korean Society for Applied Biological Chemistry 2020

\begin{abstract}
Farrerol is a flavanone isolated from the traditional Chinese herb 'Man-shan-hong' (Rhododendron dauricum L.). Farrerol has been reported to have various bioactivities including anti-oxidant, anti-inflammation, and anti-fungal. However, anticancer effect of farrerol has not yet been reported in MCF-7 breast cancer cells. In the present study, we investigated the anti-cancer effect of farrerol on MCF-7 cells. Farrerol decreased viability and induced apoptosis of MCF-7 cells in a dose dependent manner. Ferrerol exhibited a significant anti-proliferation effect with a half-maximal inhibitory concentration $\left(\mathrm{IC}_{50}\right)$ values of $145.04 \pm 1.4$ $\mu \mathrm{M}$ in MTT assay, when MCF-7 cells were treated with ferrerol for $48 \mathrm{~h}$. Also, ferrerol induced apoptotic bodies of MCF-7 cells as evaluated by TUNEL assay and Annexin V/PI staining using FACS. By mechanism of action, ferrerol regulated the activation of $\mathrm{p} 38$ mitogen-activated protein kinase and altered the expression level of BAX, Bcl-2, and Poly ADP Ribose Polymerase in MCF7 cells. In summary, our finding demonstrated that ferrerol has
\end{abstract}

Ju-Ock Nam $(\bowtie)$

E-mail:namjo@knu.ac.kr

${ }^{1}$ Department of Food Science and Biotechnology, Kyungpook National University, 80 Daehakro, Bukgu, Daegu 41566, Republic of Korea

${ }^{2}$ Institute of Agricultural Science \& Technology, Kyungpook National University, Daegu 41566, Republic of Korea

This is an Open Access article distributed under the terms of the Creative Commons Attribution Non-Commercial License (http://creativecommons. org/licenses/by-nc/3.0/) which permits unrestricted non-commercial use, distribution, and reproduction in any medium, provided the original work is properly cited. anti-cancer effect through regulating the activation and expression of apoptosis-related proteins in MCF-7 cells.

Keywords Anti-cacner - Apoptosis - Breast cancer - Farrerol · $\mathrm{MCF}-7$

\section{서 론}

오늘날까지도 여전히 난치성 질환으로 분류되는 암은 국내 전 체 사망원인 중 가장 높은 비중을 차지하고 있다[1]. 여러 종류 의 암 중, 특히 유방암으로 인한 국내 여성 암환자의 사망률은 매년 증가하는 추세이며 현대인들의 변화한 고단백, 고지방식습 관이 대표적인 유방암의 유발원인으로 평가되고 있다[2]. 이러 한 유방암을 타개할 수 있는 예방 및 치료제 개발에 대한 많은 연구가 지속적으로 이루어지고 있으며 최근에는 다양한 천연소 재물질의 우수한 유방암 치료효과가 다수 보고되며[3], 근 감소, 구토, 백혈구 감소 증 등 심각한 부작용을 동반하는 기존 항암 제의 대체가능성이 제시되고 있다[4-6].

항암 치료의 가장 중요한 전략 중 하나는, 세포사멸(apoptosis) 경로를 통해 암세포의 죽음을 유도하는 것이다. Apoptosis는 선 택적인 세포 소실을 일으키는 생리적인 과정으로 조직의 항상 성 유지에 필수적인 조절 작용이다. 세포사멸은 세포 내외의 세 포사멸 신호에 의해 시작되어 최종적으로 caspase (Cysteineaspartic protease)를 활성화시키고, 활성화된 caspase에 의해 Poly ADP Ribose Polymerase (PARP)의 절단이 일어나면서 세포자살이 진행된다[7]. Apoptosis를 조절하는 경로 중, 세포의 증식, 분화, 사멸 등 다양한 현상을 조절하는 mitogen-activated 
protein kinase (MAPK)는 세포 외 자극을 세포막에서부터 세포 내 핵까지 전달하는 대표적인 signal pathway로 성장호르몬, 사 이토카인, 스트레스 등의 수용체로부터 활성화된 신호를 세포 내로 전달한다. MAPK는 크게 ERK (세포의 신호활성 효소), JNK (c-JUN N-terminal 활성효소), p38 MAPK로 분류할 수 있고[8], 스트레스 활성 효소로 분류되는 p38 MAPK의 활성화 는 염증 반응, 세포 사멸 등을 유도하는 것으로 알려져 있다 $[9,10]$

Farrerol은 중국에서 전통 약용 식물로 사용되는 산진달래 (Rhododendron dauricum L.)에서 유래된 flavanone으로 보고되 어 있다[11]. Farrerol은 항균, 항염증, 항 노화 작용과 같은 다 양한 약리효과가 보고되어 있을 뿐만 아니라 위암세포의 증식 억제 및 세포 사멸 유도 등의 항암효과가 보고된 바 있다[1218]. 그러나, 아직까지 MCF-7 인간 유방암 세포주에 대한 farrerol의 항암효과 및 이의 기전에 관한 연구는 보고된 바 없 다. 그러므로, 본 연구에서는 farrerolo이 MCF-7인간 유방암 세 포주의 세포증식 및 Apoptosis에 미치는 영향과 이에 관한 분 자적 기전에 대해 규명하고자 한다.

\section{재료 및 방법}

\section{실험 재료}

본 실험에서 사용한 farrerol은 Chem Faces (Wuhan, China)에 서 구입하였고 dimethyl sulfoxide에 $40 \mathrm{mM}$ 농도로 용해한 뒤 $-20{ }^{\circ} \mathrm{C}$ 에 보관하였다. Western blot에 사용한 Anti-body는 p38, p-p38, PARP, BAX, Bcl-2는 Cell signaling technology (Beverly, MA, USA)사에서, $\beta$-Actin과 Muouse, rabbit 2차항체 는 Sant Cruz Biotechnology (Santa Cruz, MA, USA)사에서 구입하였다. p38 Inhibitor로 사용된 SB 203580(CAS 15212147-6)은 Sigma Aldrich사에서 구입하였다.

\section{세포주 및 세포배양}

인간 유방암 세포주 MCF-7은 한국세포주은행(Seoul, Korea)에 서 구입하였고, $10 \%$ fetal bovine serum (FBS)이 함유된 Roswell Park Memorial Institute medium-1640 (RPMI-1640) 배지를 사용하여 $37{ }^{\circ} \mathrm{C}, 5 \% \mathrm{CO}_{2}$ Incubator에서 배양하였다. RPMI-1640 및 FBS는 Gibco Life Technologies (Grand Island, NY, USA)로부터 구입하였다. 배양 중인 세포의 배지는 23일에 한번 새로운 배지로 교체해주었다.

\section{세포 생존율 측정(MTT Assay)}

MCF-7 세포를 96-well plates에 각 well 당 $2 \times 10^{5}$ 개의 세포로 $100 \mu \mathrm{L}$ 의 배지와 함께 분주하고 $5 \% \mathrm{CO}_{2}$ 가 공급되는 incubator 에서 24시간 동안 배양한 후, 각 well 마다 Farrerol을 0, 40, $80,160 \mu \mathrm{M}$ 농도로 처리하고 24,48 시간 배양하였다. 배양 후 medium을 제거하고 MTT solution을 $0.4 \mathrm{mg} / \mathrm{mL}$ 농도로 120 $\mu \mathrm{L}$ 씩 well 마다 분주하고 incubator에서 3시간 배양한 뒤 제거 하고 iso-propyl alcohol (DUKSAN, Ansan, Korea)을 $100 \mu \mathrm{L} /$ well 넣어 생성된 formazan을 용해시킨 뒤, infinite reader를 이 용하여 $595 \mathrm{~nm}$ 에서 흡광도를 측정했다.

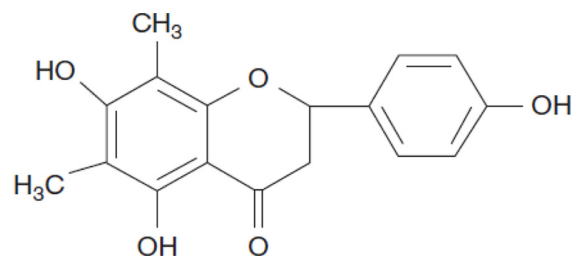

Fig. 1 The chemical structure of farrerol

\section{TUNEL assay}

MCF-7 세포를 chamber slide (Cell Culture Slide II,SPL, Pocheon, Korea)에 well 당 $2 \times 10^{5}$ 개의 세포를 $100 \mu \mathrm{L}$ 의 배지와 함께 분주하고 $5 \% \mathrm{CO}_{2}$ 가 공급되는 incubator에서 24시간 동안 배양한 후, 각 well 마다 farrerol을 $0,40,80,160 \mu \mathrm{M}$ 농도로 처리하고 48시간 배양하였다.

Farrerol을 48시간 처리한 뒤 배지를 제거하고, $6 \%$ Glutar aldehyde를 분주하여 10 분 고정시키고, $70 \% \mathrm{EtOH}$ 를 이용하여 10 분 고정시켰다. 이후 $\mathrm{PBS}$ 에 희석된 $0.25 \%$ Triton X-100을 15 분 처리하고, In situ BrdU-Red DNA Fragmentation kit (ab66110, abcam, Cambridge, UK)을 이용하여 TUNEL 염색을 제품의 매뉴얼 대로 진행하였다. TUNEL 염색이 끝난 뒤, DAPI 염색을 진행하고 형광현미경을 이용하여 관찰하였다.

\section{FACS를 이용한 Annexin V/PI 측정}

Annexin V-FITC Apoptosis Detection Kit II (BD 556570, BD Bioscience, San Jose, CA, USA)을 이용하여 farrerol이 처리된 세포에서 apoptosis를 확인하기 위하여 phosphatidylserine 의 이동을 측정하였다. $\mathrm{MCF}-7$ 세포에 farrerol을 48시간 처리 한 뒤 PBS로 세척하고 annexin V와 PI가 혼합된 binding 버 퍼를 이용하여 상온에서 15 분간 염색시킨 뒤 flow cytometer (Attune NxT; ThermoFisher, Eugene, OR, USA)를 이용하여 annexin $\mathrm{V}$ positive와 PI positive 세포들을 측정하였다.

\section{Wetern blot}

Farrerol을 농도 별로 24, 48시간 $\mathrm{MCF}-7$ 세포에 처리한 후 배 지와 시료를 제거하고 RIPA lysis buffer (Biosesang, Seongnam, Korea)로 용해하여 $12,000 \mathrm{rpm}$ 에서 $4{ }^{\circ} \mathrm{C}, 10$ 분간 원심분리 하고 상층액에 있는 단백질을 얻었다. 추출한 단백질을 SDS-Loading buffer와 $4: 1$ 로 혼합하여 $100{ }^{\circ} \mathrm{C}$ 에서 10 분간 가열하여 Sample 을 얻었고 동일한 양의 단백질을 $7.5-15 \%$ SDS-polyacrylamide gel에 각 sample을 loading하여 전기영동으로 gel상에 단백질을 분리하고, nitrocellulose $(\mathrm{NC})$ membrane에 전달시켰다. $\mathrm{NC}$ membrane에 전달한 뒤, TBST (10 mM TRIS, $150 \mathrm{mM} \mathrm{NaCl}$ 및 $0.05 \%$ Tween 20)에 희석한 5\% skim milk로 blocking한 후, $\mathrm{p} 38, \mathrm{p}-\mathrm{p} 38, \mathrm{BAX}, \mathrm{Bcl}-2, \mathrm{PARP}$ 및 $\beta$-actin 각각의 1 차 항체를 $1: 1000$ 으로 $4{ }^{\circ} \mathrm{C}$ 에서 overnight 처리하였고 2 차 항체는 mouse 1:2000, rabbit 1:3000으로 상온에서 1시간 반응시켰다. 반응 후, enhanced chemiluminescence (GE Healthcare, Menlo Park, CA, USA)를 membrane에 도포하고 Fusion solo를 사용 하여 각각의 단백질 밴드를 확인하였다. 단백질의 상대적 발현 수준은 Image-J를 사용하여 정량화 하였다. 


\section{Caspase-3 activity assay}

Farrerol의 처리에 의한 caspase-3 활성의 변화를 측정하기 위해 caspase-3/Colorimetric Assay Kit (ab39401, abcam, Cambridge, $\mathrm{UK}$ )를 이용하였다. 실험 절차는 제공된 프로토콜을 따랐고, infinite reader를 이용하여 $405 \mathrm{~nm}$ 에서 흡광도를 측정했다.

\section{통계 분석}

모든 실험결과는 평균 \pm 표준오차(standard error, SE)로 표현하였 다. 통계 분석은 최소 3 개의 생물학적 복제물에 대한 실험을 위 해 일원 분산 분석(one-way ANOVA)을 사용하여 수행되었다. $p<0.05$ 는 통계적으로 유의하다고 간주되었다.

\section{결과 및 고찰}

본 연구는 farrerol의 MCF-7에 대한 항암활성을 확인하고자 수 행하였다.

\section{Farrerol에 의한 MCF-7 세포의 세포 증식 억제 효과}

Farrerol의 MCF-7 세포에 대한 세포 증식 억제 효과를 확인하 기 위해 $2 \times 10^{5}$ 개의 MCF-7 세포에 farrerol을 $0,40,80,160$ $\mathrm{iM}$ 을 각각 처리하고 24,48 시간 배양한 뒤 광학현미경 상으로 세포를 관찰한 결과 세포의 수가 farrerol의 농도 및 시간 의존 적으로 감소하는 것을 나타냈다(Fig. 2A). 이어서 세포생존율을 확인하기 위해 MTT assay를 진행하였다. farrerol을 24시간 처 리한 MCF-7 세포에서는 $160 \mu \mathrm{M}$ 처리군에서 $77.4 \%$ 의 세포생 존율을 보여주며 $\mathrm{IC}_{50}$ 값이 $289.7 \pm 11.5 \mu \mathrm{M}$ 로써 $\mathrm{MCF}-7$ 세포에
대한 farrerol의 24시간 처리의 세포증식억제 효과가 약하게 나 타났다. 하지만 MCF-7 세포에 farrerol 48시간 처리는 농도의 존적으로 세포생존율이 감소했으며 $160 \mu \mathrm{M}$ 처리 농도에서 $40.2 \%$ 의 세포생존율을 나타냈고, $145.04 \pm 1.4 \mu \mathrm{M}$ 의 $\mathrm{IC}_{50}$ 값을 보여주므로 farrerol의 48시간 처리에서 $\mathrm{MCF}-7$ 세포의 증식을 억제를 나타낸다 (Fig. 2B).

\section{Farrerol에 의한 MCF-7 세포의 apoptosis 유도 효과}

MCF-7 세포에 대한 farrerol의 세포 증식 억제 효과가 apoptosis에 의해 기인하는 것인지를 확인하기 위하여 TUNEL assay와 Annexin V/PI staining을 진행하여 apoptotic cells의 변화를 측정하였다. Farrerol을 $0,40,80,160 \mu \mathrm{M}$ 농도로 48 시 간 처리한 $\mathrm{MCF}-7$ 세포를 TUNEL 염색한 결과, 농도 의존적으 로 TUNEL positive 세포의 증가를 나타냈고(Fig. 3A, B), $\mathrm{FACS}$ 를 이용한 Annexin V/PI 염색 및 측정 결과 또한 농도 의존적으로 40 및 $80 \mu \mathrm{M}$ 의 농도에서 Annexin $\mathrm{V}$ 양성인 apoptotic cell의 양이 증가되는 것을 나타냈다. 이러한 결과를 바탕으로 farrerol의 처리에 의한 $\mathrm{MCF}-7$ 세포의 증식억제가 apoptosis 유도에 의해 기인하는 것을 확인했다(Figs. 3C, D).

\section{MCF-7 세포에서 farrerol에 의한 Apoptosis 관련 단백질 발현 량의 변화}

TUNEL assay와 FACS를 이용한 Annexin V/PI 측정 결과를 바탕으로 farrerol에 의한 MCF-7의 apoptosis의 증가의 메커니 즘을 확인하기 위해, western blotting을 통해 apoptosis 관련 단 백질의 발현량을 조사하였다. Apoptosis는 세포 내외적인 여러 세포사멸 신호전달 경로를 통하여 진행되는데, 그 중 대표적으

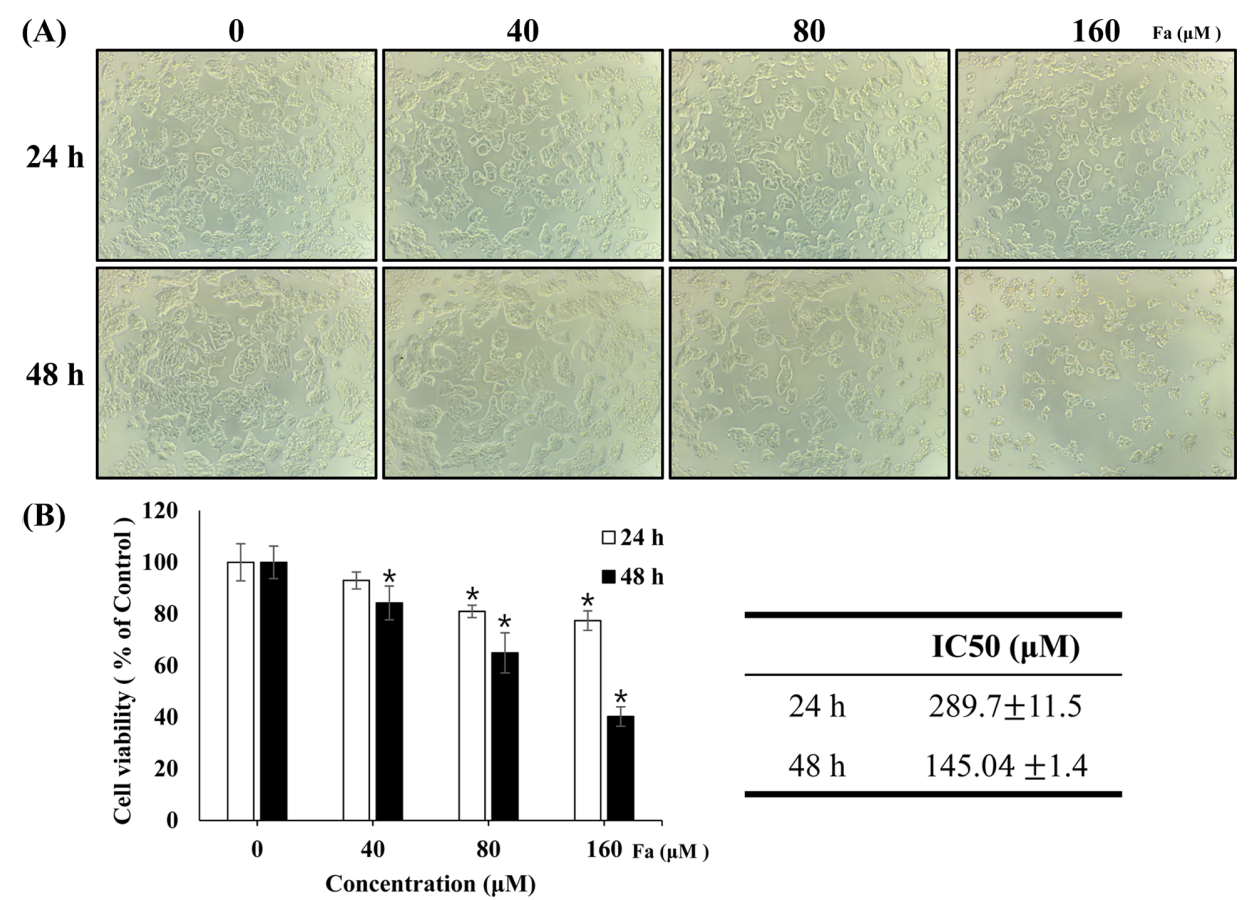

Fig. 2 Effect of farrerol on the viability of MCF-7 cells. (A) Optical microscope images of MCF-7 cells confluency after treatment with the indicated concentration of FA for 24 and $48 \mathrm{~h}$. (B) MCF-7 cells were treated with various concentrations of farrerol (0, 40, 80, $160 \mu \mathrm{M})$ for $24 \mathrm{~h}$ or $48 \mathrm{~h}$. Cell viability was measured by the MTT assay $(*$, compared with control, $p<0.05)$ 
(A)

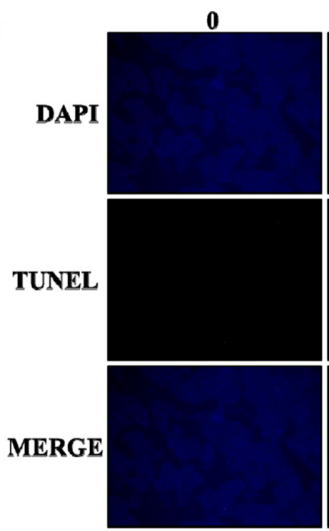

(C)

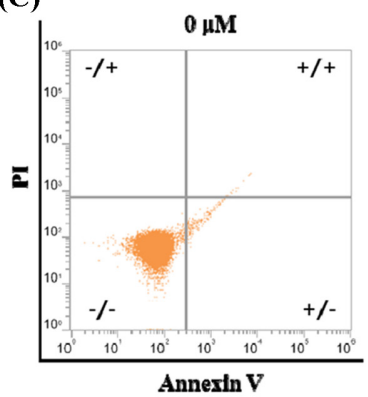

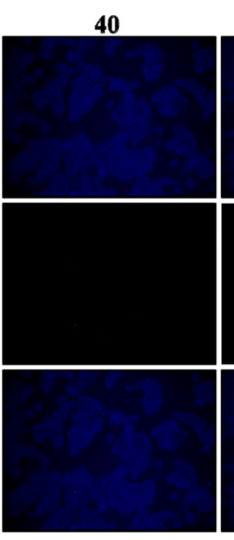

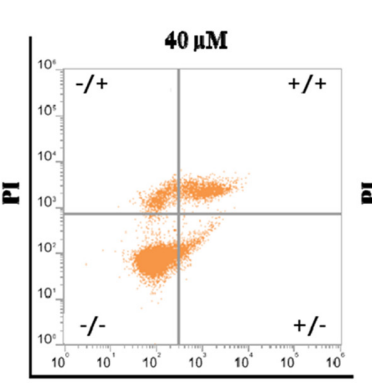

Annexin V
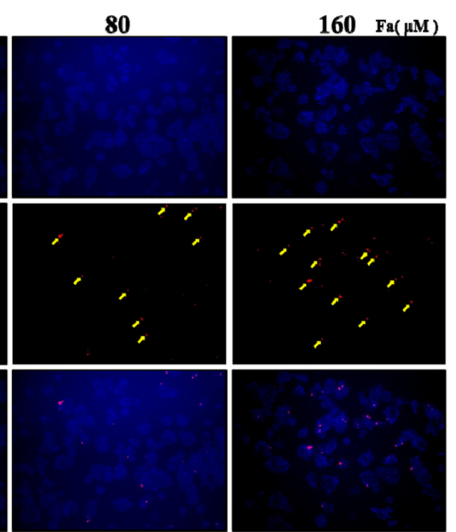

$80 \mu \mathrm{M}$

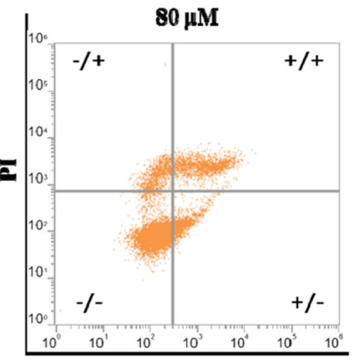

Annexin V

\begin{tabular}{cccccc}
\hline & \multirow{5}{*}{ Conc. } & \multicolumn{4}{c}{ Population of cells (\%) } \\
\cline { 2 - 6 } & Ltve cells $(-/-)$ & Necrosls cells $(-/+)$ & Earty apoptotlc cells $(+/-)$ & Late apoptotlc cells $(+/+)$ \\
\hline \multirow{2}{*}{ Farrerol } & 0 & 99.376 & 0.000 & 0.566 & 0.058 \\
\cline { 2 - 6 }$(\mu \mathrm{M})$ & $\mathbf{4 0}$ & 75.474 & 6.698 & 4.880 & 12.949 \\
\cline { 2 - 6 } & $\mathbf{8 0}$ & 70.148 & 7.487 & 9.832 & 12.534 \\
\hline
\end{tabular}

(B)

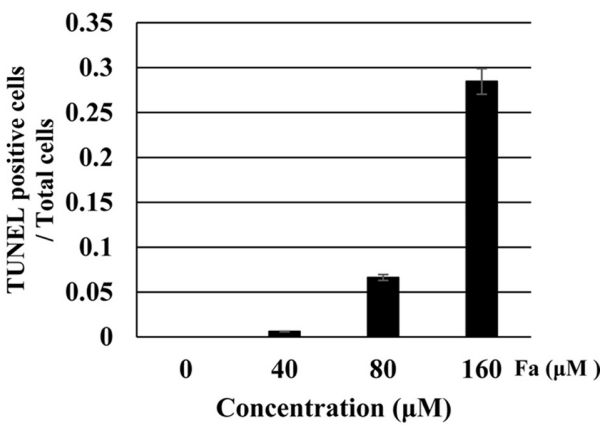

(D)

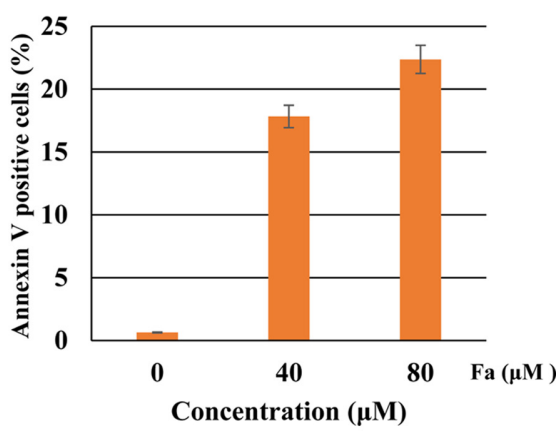

Fig. 3 Farrerol induces apoptosis in MCF-7 cells. The cells were treated with farrerol $(0,40,80,160 \mu \mathrm{M})$ for $48 \mathrm{~h}$ and then stained using TUNEL and DAPI. (A) Farrerol treatment increased the number of TUNEL-positive cells in a dose-dependent manner. (B) The graph shows the average number of fluorescence dots in the images from each treatment group. (C) Annexin V/PI staining to Farrerol treated MCF-7 cells measure by using FACS. (D) The graph shows the average number of Annexin $\mathrm{V}$ positive cells in the images from each treatment group

로 MAPK signal pathway가 있고 이는 ERK, JNK, p38 MAPK 로 분류할 수 있다[8].

$\mathrm{MAPK}$ 중 $\mathrm{ERK}$ 및 $\mathrm{JNK}$ 는 세포 생존, 세포 증식, antiapoptosis에 주로 관여한다고 잘 알려저 있고, 스트레스 활성 효 소로 분류되는 $\mathrm{p} 38 \mathrm{MAPK}$ 의 활성화는 염증 반응, 세포 사멸 등을 유도하는 것으로 알려져 있다[9,10]. 따라서 본 연구에서 는 farrerol의 처리에 의한 p38 MAPK 활성에 집중하여 분석하 였다. 또 다른 경로로는 내인성 세포사멸(Intrinsic apoptosis)이 있다. 내인성 세포사멸은 사이토크롬 $\mathrm{C}$ 의 방출 및 Apoptosome 의 형성을 유도함으로써 미토콘드리아를 매개하는 경로를 활성 화시킨다. 이러한 사멸 경로는 주로 $\mathrm{Bax}, \mathrm{Bak}$ 및 $\mathrm{Bid}$ 및 antiapoptosis 단백질 $\mathrm{Bcl}-2, \mathrm{Bcl}-\mathrm{xL}$ 을 포함한 단백질에 의해 제어된 다[19].

본 실험의 결과 farrerol의 처리는 mitochondria 상에 위치하 며 apoptosis에 관여하는 $\mathrm{BAX}$ 의 발현은 farrerol의 처리에 따라 농도의존적으로 증가했고, pro-survival에 관여하는 $\mathrm{Bcl}-2$ 의 발 현은 farrerol의 처리에 따라 감소하여, farrerol의 처리에 의해 $\mathrm{BAX} / \mathrm{Bcl}-2$ 의 발현 비율은 대조군에 비해 $160 \mathrm{iM}$ 농도 처리군 에서 5.7배 가량 증가함을 확인했다(Fig. $4 \mathrm{~A}, \mathrm{~B})$. 추가적으로, apoptosis가 진행될 때 PARP $(116 \mathrm{kDa})$ 의 절단이 동반되는데, 이 또한 farrerol의 처리에 의해 절단된 PARP $(89 \mathrm{kDa})$ 가 증가 되는 것을 western blot을 통해 확인하였고(Fig. 4A, C), Caspase-3의 활성 역시 농도 의존적으로 증가하는 것을 확인했 다. 이러한 결과를 바탕으로 farrerol의 처리는 MCF-7 세포의 세포 자살을 촉진시키는 것으로 사료된다.

MCF-7 세포에 대한 farrerol의 처리는 p38 MAPK의 활성화 를 증가시켰다(Fig. 4A, E). Farrerol의 처리에 의한 MCF-7 세 포의 Apoptosis 유도 현상이 p38 MAPK를 매개하는지 확인하 기 위해 SB203580 (p38 Inhibitor)를 이용한 MTT assay와 $\mathrm{PARP}$ 의 분절화를 확인했다. 그 결과 $\mathrm{p} 38 \mathrm{MAPK}$ 의 억제는 farrerol의 처리에 의해 감소한 세포생존율을 증가시켰으며(Fig. $4 \mathrm{~F}), \mathrm{PARP}$ 의 분절화 역시 감소시킴을 확인함으로써 farrerol에 의한 $\mathrm{MCF}-7$ 의 세포자살 유도는 $\mathrm{p} 38$ 을 매개한다고 사료된다 (Fig. 4G, H). 하지만 추후에 p38의 상위 및 하위 신호전달 경 로 또는 다른 세포자살 유도 경로 등 더 많은 기전에 대한 탐 색과 동물실험 수준의 실험이 필요할 것이라 사료되며, 항암 활 성을 가지는 농도에서의 부작용에 대한 연구도 추가적으로 진 행할 필요가 있다. 기존의 여러 항암제는 투여 시 정상세포까 
(A)

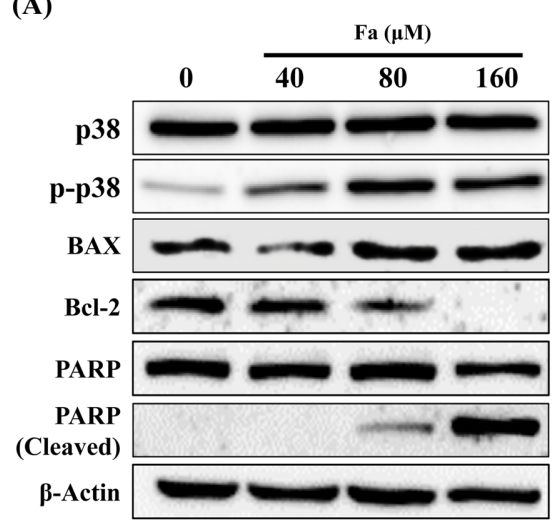

(F)

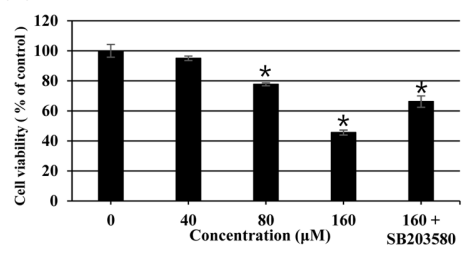

(B)

BAX/Bcl-2

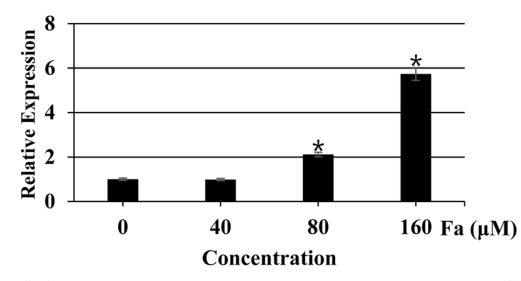

(D)

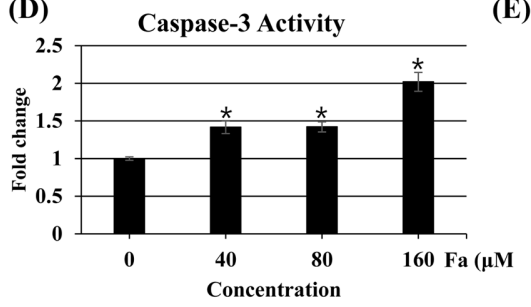

(G)

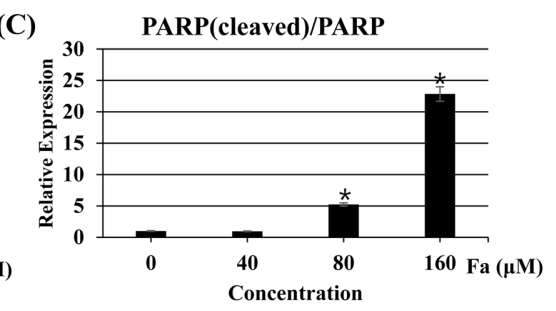

(E)

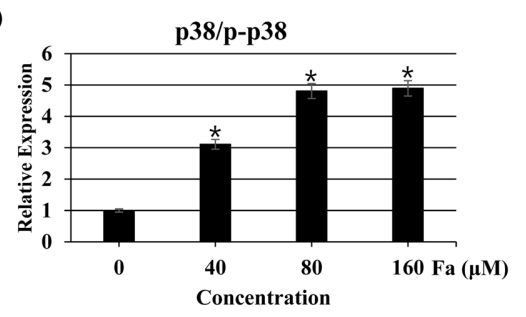

(H) PARP(cleaved)/PARP
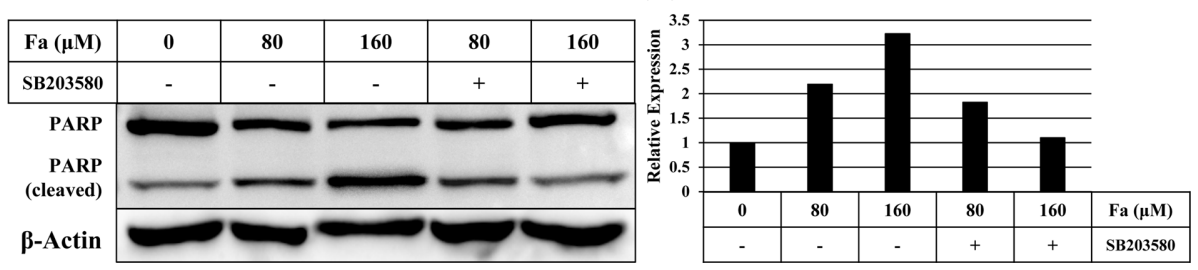

Fig. 4 The apoptotic effect of farrerol on protein expression levels of apoptosis-related genes in MCF-7 cells determind by Western blotting. (A) Expression levels of apoptotic protein in farrerol treated MCF-7 cells were detected using western blot. (B) The graph shows the expression level of BAX/Bcl-2 ratio. (C) The graph shows the expression level of cleaved PARP/PARP ratio. (D) The graph shows the result of caspase-3 assay kit. MCF7 cells were treated with various concentrations of farrerol $(0,40,80,160 \mu \mathrm{M})$ for $48 \mathrm{~h}$. (E) The graph shows the expression level of p-p38/p38 ratio. (F) The graph shows Cell viability of MCF-7 cells. MCF-7 cells were treated with various concentrations of farrerol $(0,40,80,160 \mu \mathrm{M}$ and $\mathrm{SB} 203580$ pretreated $160 \mu \mathrm{M}$ ) for $48 \mathrm{~h}$. Cell viability was measured by the MTT assay (*, compared with control, $p<0.05$ ). (G) Expression levels of PARP and cleaved PARP in farrerol treated MCF-7 cells (with or without SB203580) were detected using western blot. (H) The graph shows the expression level of cleaved PARP/PARP ratio

지 세포독성을 발생시키는 등과 같은 부작용에 대한 현상이 문 제시되어왔다. 따라서 기존 항암제를 대체할, 부작용이 없거나 기존 항암제 보다 부작용이 적은 식물 및 천연물 유래 flavonoid 또는 phenolic compound 등 phytochemical의 항암효 과에 대한 탐색과 연구의 중요성은 꾸준히 언급되어 왔다[2023]. 식물 유래 flavanone인 farrerol은 이전에 보고된 연구에서 SGC-7901 인간 위암 세포주에서 항암 활성을 나타내며, 동일 한 농도에서 비암성 정상세포인 인간 탯줄 정맥 내피세포 (HUVEC)에서 독성이 없음을 시험관 수준에서 보여주었다[13]. 하지만 부작용에 대한 연구는 동물실험, 임상시험 수준에서 더 많은 연구가 필요할 것으로 사료되고, 본 연구와 같은 시험관 수준의 증거는 farrerol을 부작용이 없는 천연물 유래 항암물질 의 후보로 가능성을 제시할 수 있다고 사료된다.

결론적으로, 본 연구에서는 farrerolo 이 $\mathrm{MCF}-7$ 인간 유방암 세 포주의 p38 MAPK의 활성화를 매개하여 apoptosis를 유도함으 로써 항암효과를 나타냄을 입증하였다.

\section{초 록}

Farrerol은 중국에서 거담제로 사용되어온 전통 한약제로 사용 된 산진달래(만산홍, Rhododendron dauricum L.)에서 유래된
플라바논이다. Farrerol은 항산화, 항염증 및 항균 작용을 포함 한 다양한 생리 활성이 보고되었다. 하지만 farrerol의 MCF-7에 대한 항암 작용은 아직 보고된 바가 없다. 본 연구에서 인간 유 방암 $\mathrm{MCF}-7$ 세포에 대한 farrerol의 처리가 세포증식을 억제하 고 apoptosis를 유도함을 입증하였다. MCF-7 세포에 ferrerol을 48시간 동안 처리했을 때, 이는 통계적으로 유의한 세포증식 효 과를 나타냈으며 이의 $\mathrm{IC}_{50}$ 값은 $145.04 \pm 1.4 \mu \mathrm{M}$ 임을 확인하였 다. 또한, farrerol이 세포사멸을 유도함을 TUNEL assay와 $\mathrm{FACS}$ 를 이용한 Annexin V/PI 염색을 통해 검증하였다. 이러한 항암 효능의 작용기전으로써, farrerol의 처리가 $\mathrm{BAX} / \mathrm{Bcl}-2$ 및 Caspase-3활성화와 PARP 분절화를 증가시켜 세포자살을 촉진 한다는 것을 확인하였다. 결론적으로, 본 연구의 결과는 farrerol 이 apopotosis 관련 단백질의 활성 및 발현조절을 통해 $\mathrm{MCF}-7$ 유방암세포에 대한 항암 효능을 갖는다는 것을 보여주고 있다.

\section{Keywords 세포사멸사 · 유방암 - 파르레롤 - 항암 · MCF-7}

\section{References}

1. Jung KW, Won YJ, Kong HJ, Lee ES (2018) Prediction of cancer incidence and mortality in Korea, 2018. Cancer Res Treat 50: 317

2. Wu C, Ray RM, Lin MG, Gao DL, Horner NK, Nelson ZC, Lampe JW, 
Hu YW, Shannon J, Stalsberg H (2004) A case-control study of risk factors for fibrocystic breast conditions: Shanghai Nutrition and Breast Disease Study, China, 1995-2000. Am J Epidemiol 160: 945-960

3. Woyengo T, Ramprasath V, Jones P (2009) Anticancer effects of phytosterols. Eur J Clin Nutr 63: 813-820

4. Kim MY, Bo HH, Choi EO, Kwon DH, Kim HJ, Im Ahn K, Ji SY, Jeong J-W, Park S-H, Hong S-H (2018) Induction of apoptosis by Citrus unshiu Peel in human breast cancer MCF-7 cells: Involvement of ROSdependent activation of AMPK. Biol Pharm Bull 41: 713-721

5. Longman AJ, Braden CJ, Mishel MH (1996) Side effects burden in women with breast cancer. Cancer Practice 4: 274-280

6. Ansari L, Shiehzadeh F, Taherzadeh Z, Nikoofal-Sahlabadi S, MomtaziBorojeni A, Sahebkar A, Eslami S (2017) The most prevalent side effects of pegylated liposomal doxorubicin monotherapy in women with metastatic breast cancer: a systematic review of clinical trials. Cancer Gene Ther 24: 189-193

7. Elmore S (2007) Apoptosis: a review of programmed cell death. Toxicol Pathol 35: 495-516

8. Xia Z, Dickens M, Raingeaud J, Davis RJ, Greenberg ME (1995) Opposing effects of ERK and JNK-p38 MAP kinases on apoptosis. Science 270: 1326-1331

9. Borsello T, Clarke PG, Hirt L, Vercelli A, Repici M, Schorderet DF, Bogousslavsky J, Bonny C (2003) A peptide inhibitor of c-Jun Nterminal kinase protects against excitotoxicity and cerebral ischemia. Nat Med 9: 1180-1186

10. Wada T, Penninger JM (2004) Mitogen-activated protein kinases in apoptosis regulation. Oncogene 23: 2838-2849 doi:10.1038/sj.onc. 1207556

11. Peng YY, Liu FH, Ye JN (2004) Determination of Bioactive Flavonoids in Rhododendron Dauricum L. by Capillary Electrophoresis with Electrochemical Detection. Chromatographia 60: 597-602 doi:10.1365/ s10337-004-0420-8

12. Cao Y, Chu Q, Ye J (2004) Chromatographic and electrophoretic methods for pharmaceutically active compounds in Rhododendron dauricum. J Chromatogr B Analyt Technol Biomed Life Sci 812: 231240

13. Liu E, Liang T, Wang X, Ban S, Han L, Li Q (2015) Apoptosis induced by farrerol in human gastric cancer SGC-7901 cells through the mitochondrial-mediated pathway. Eur J Cancer Prev 24: 365-372

14. Ci X, Chu X, Wei M, Yang X, Cai Q, Deng X (2012) Different effects of farrerol on an OVA-induced allergic asthma and LPS-induced acute lung injury. PLoS ONE 7

15. Dai F, Gao L, Zhao Y, Wang C, Xie S (2016) Farrerol inhibited angiogenesis through Akt/mTOR, Erk and Jak2/Stat3 signal pathway. Phytomedicine 23: 686-693

16. Li Qy, Chen L, Zhu Yh, Zhang M, Wang Yp, Wang Mw (2011) Involvement of estrogen receptor-â in farrerol inhibition of rat thoracic aorta vascular smooth muscle cell proliferation. Acta Pharmacol Sin 32: 433-440

17. Qiu J, Xiang H, Hu C, Wang Q, Dong J, Li H, Luo M, Wang J, Deng X (2011) Subinhibitory concentrations of farrerol reduce $\alpha$-toxin expression in Staphylococcus aureus. FEMS Microbiol Lett 315: 129-133

18. Liu E, Li J, Shi S, Wang X, Liang T, Wu B, Li Q (2016) Sustained ERK activation-mediated proliferation inhibition of farrerol on human gastric carcinoma cell line by G0/G1-phase cell-cycle arrest. Eur J Cancer Prev 25: 490-499

19. Boise LH, González-García M, Postema CE, Ding L, Lindsten T, Turka LA, Mao X, Nuñez G, Thompson CB (1993) bcl-x, a bcl-2-related gene that functions as a dominant regulator of apoptotic cell death. Cell 74: 597-608

20. Lu R, Serrero G (1999) Resveratrol, a natural product derived from grape, exhibits antiestrogenic activity and inhibits the growth of human breast cancer cells. J Cell Physiol 179: 297-304

21. Wang W, Zhang X, Qin J-J, Voruganti S, Nag SA, Wang M-H, Wang H, Zhang R (2012) Natural product ginsenoside 25-OCH3-PPD inhibits breast cancer growth and metastasis through down-regulating MDM2. PLoS ONE 7

22. Ledford H (2010) Complex synthesis yields breast-cancer therapy. Nature 468: 608-609

23. Verma SP, Salamone E, Goldin B (1997) Curcumin and genistein, plant natural products, show synergistic inhibitory effects on the growth of human breast cancer MCF-7 cells induced by estrogenic pesticides. Biochem Biophys Res Commun 233: 692-696 